\title{
Pharmacological modulation of gastric emptying rate of solids as measured by the carbon labelled octanoic acid breath test: influence of erythromycin and propantheline
}

\author{
B D Maes, M I Hiele, B J Geypens, P J Rutgeerts, Y F Ghoos, G Vantrappen
}

\begin{abstract}
The ${ }^{\star} \mathrm{C}\left({ }^{13} \mathrm{C}\right.$ or $\left.{ }^{14} \mathrm{C}\right)$ labelled octanoic acid breath test was recently developed to measure the gastric emptying rate of solids. This study aimed to investigate whether it is sensitive enough to detect pharmacologically induced changes in the gastric emptying rate. Nine healthy volunteers were studied in basal condition, after intravenous administration of $\mathbf{2 0 0}$ mg erythromycin, and after peroral administration of $\mathbf{3 0} \mathrm{mg}$ propantheline. Erythromycin significantly enhanced gastric emptying in all subjects, with an increase of the gastric emptying coefficient $(p=0.0043)$ in eight of nine and a fall in both the gastric half emptying time $(p=0.0020)$ and the lag phase $(p=0.0044)$ in all nine. Propantheline significantly reduced the gastric emptying rate, with a decreased gastric emptying coefficient $(p=0.0007)$ and an increased gastric half emptying time $(p=0.0168)$ in all subjects, but no change in the lag phase $(p=0.1214)$. Further mathematical analysis showed that breath sampling at 15 minutes intervals over a four hour period is recommended to guarantee accuracy and the discriminative value of the breath test in various gastric emptying patterns. In conclusion the ${ }^{\star} \mathrm{C}$ labelled octanoic acid breath test is sufficiently sensitive to show pharmacologically induced changes of gastric emptying rates of solids.
\end{abstract}

(Gut 1994; 35: 333-337)

Gastric emptying is susceptible to a wide variety of external influences, ${ }^{1-7}$ including drugs. ${ }^{8-13}$ Care should be taken when interpreting gastric emptying studies in patients taking drugs with a long biological half-life. On the other hand, gastrointestinal side effects of some drugs may prove to be of interesting clinical value, as was recently shown for some macrolide antibiotics. ${ }^{13-16}$

$\mathrm{A} \star \mathrm{C}\left({ }^{13} \mathrm{C}\right.$ or $\left.{ }^{14} \mathrm{C}\right)$ octanoic acid breath test was recently developed to measure the gastric emptying rate of solids. ${ }^{17}{ }^{\star} \mathrm{C}$ octanoic acid, a medium chain fatty acid, is readily solubilised in egg yolk. When cooked as an omelette it has proved to be as good a marker of the solid phase of a meal as the radioscintigraphic markers for gastric emptying studies. ${ }^{17}$ Once the egg yolk reaches the duodenum, rapid disintegration of the labelled solid phase occurs with subsequent absorption and preferential hepatic oxidation of ${ }^{\star} \mathrm{C}$ octanoic acid to ${ }^{\star} \mathrm{CO}_{2} \cdot{ }^{18-20}$ Since gastric emptying of the meal is the rate-limiting step in the whole process, the rate of ${ }^{\star} \mathrm{CO}_{2}$ excretion in the breath as a function of time can be used to measure the gastric emptying rate. In a validation study, with simultaneous radioscintigraphic and breath test measurements, an excellent correlation was found between the gastric emptying results of the radioscintigraphic method (lag phase, half emptying time) and those of the breath test (lag phase, half emptying time, and the gastric emptying coefficient) when using a solid standard test meal of $250 \mathrm{kcal}$. The breath test was both sensitive and specific when discriminating between normal and delayed gastric emptying. ${ }^{17}$

In this study, we wanted to investigate the sensitivity of the ${ }^{\star} \mathrm{C}$ labelled octanoic acid breath test in measuring even minor drug induced changes in the gastric emptying rate of solids in individual healthy volunteers. Two drugs with a known influence on gastrointestinal motor activity were used - erythromycin, which accelerates, ${ }^{13}$ and propantheline, which delays gastric emptying. ${ }^{1222-23}$

\section{Methods}

\section{SUBJECTS}

Nine healthy volunteers (five men and four women; mean age 22 years, range 18 to 25 years) were studied. None had a history of gastrointestinal disease or surgery, or was taking any medication. The gastric emptying rate of a solid standard meal was measured by means of the ${ }^{14} \mathrm{C}$ octanoic acid breath test.

Each subject was studied on three consecutive days in three different randomly applied test situations - without medication, 30 minutes after intravenous administration of $200 \mathrm{mg}$ of erythromycin (erythromycin lactobionate, Abbott) in $250 \mathrm{ml}$ of $\mathrm{NaCl} 0.9 \%$ over a 15 minute period, and 60 minutes after peroral administration of 30 $\mathrm{mg}$ of propantheline (propantheline bromide, Continental Pharma).

\section{MATERIALS}

All tests were carried out after an overnight fast. The test meal consisted of two slices of white bread and an egg, the yolk of which was doped with $2 \mu \mathrm{Ci}$ of ${ }^{14} \mathrm{C}$ octanoic acid, sodium salt (DuPont, NEN Reserarch, Boston, MA, USA). The egg yolk and white were cooked separately to avoid incorporation of octanoic acid into the protein structure of the white. All meals were consumed within a five minute period. The 
subjects were allowed to drink $150 \mathrm{ml}$ of water immediately after consuming the meal. The caloric value of the meal was $250 \mathrm{kcal}$.

\section{MEASURING TECHNIQUES}

Breath samples were taken before the meal, at three minute intervals for a period of 90 minutes, and at 30 minute intervals from 90 to 240 minutes after ingestion of the meal. At each sampling point, the subjects exhaled into a liquid scintillation vial containing $2 \mathrm{ml}$ of $1 \mathrm{M}$ hyamine hydroxide and $2 \mathrm{ml}$ of ethanol together with 1 drop of thymolphthalein solution. This amount of hyamine is neutralised by $2 \mathrm{mM}$ of $\mathrm{CO}_{2}$. The end point of neutralisation is indicated by

Figure 1: Results of ${ }^{\star} C$ octanoic acid breath test in a typical case. $(B)$ represents a normal gastric emptying pattern, $(A)$ the pattern after administration of erythromycin, and $(C)$ the pattern after administration of propantheline.

\section{Figure 2: Mean values of
${ }_{14} \mathrm{CO}_{2}$ excretion for the nin subjects in the normal situation, after erythromycin, and after propantheline, with the mathematical fitted curves (solid lines).}
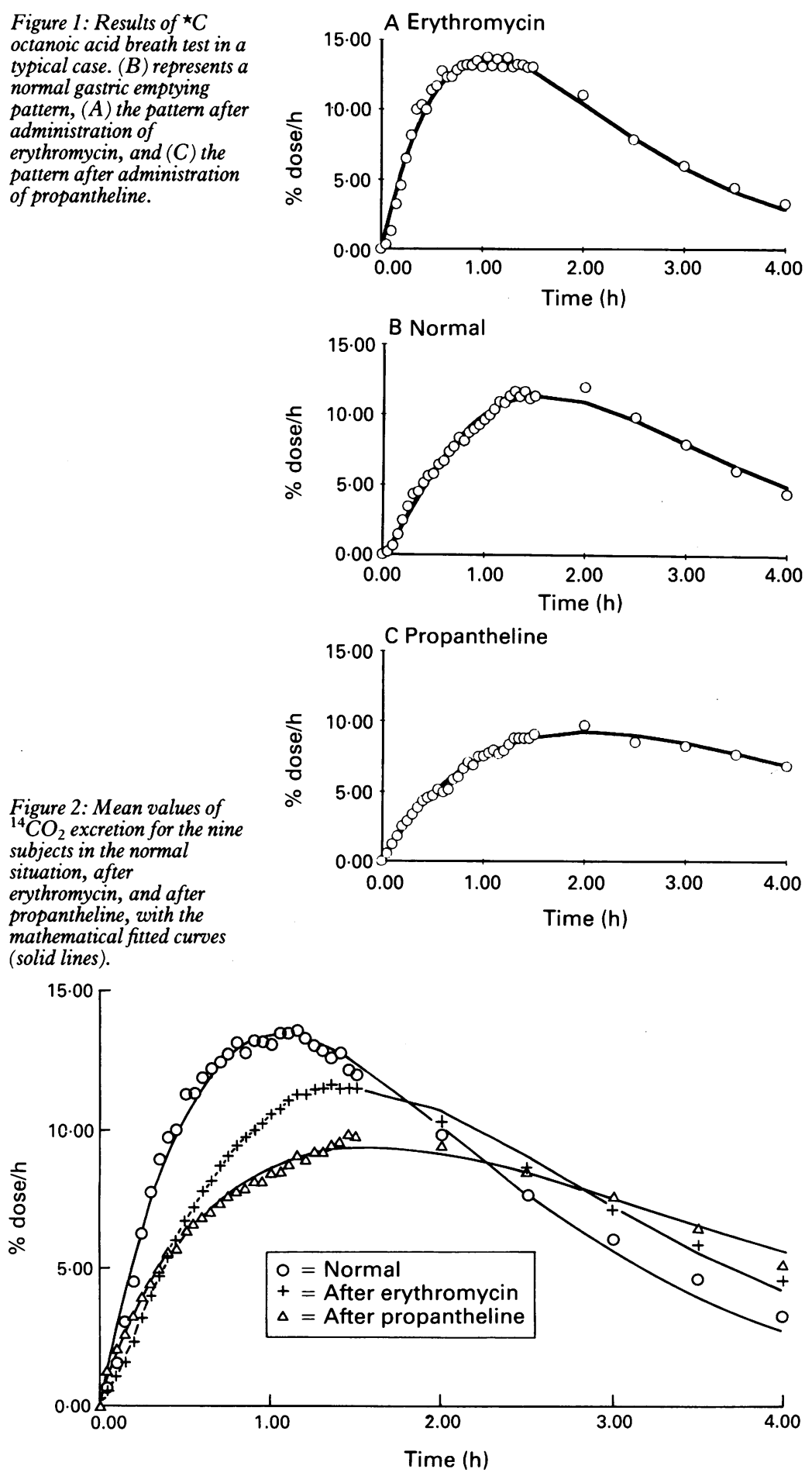

decolouration of the indicator. After decolouration, $10 \mathrm{ml}$ of scintillation cocktail (Hionic Fluor, Packard) were added and radioactivity was determined by liquid scintillation spectrometry (Packard Tri-Carb Liquid Scintillation Spectrometer, model 3375, Packard Instruments Inc, Downers Grove, IL, USA). $\mathrm{CO}_{2}$ production was assumed to be $300 \mathrm{mmol} / \mathrm{m}^{2}$ body surface area per hour. Body surface area was calculated using the weight-height formula of Haycock et al..$^{21}$ The results were expressed as the percentage of ${ }^{14} \mathrm{C}$ recovery per hour.

\section{MATHEMATICAL AND STATISTICAL ANALYSIS OF} THE RESULTS

The mathematical analysis of test results is described in a previous paper.' Briefly, the curves with the measured ${ }^{\star} \mathrm{CO}_{2}$ recovery in breath, expressed as percentage excretion per hour of the given ${ }^{\star} \mathrm{C}$ dose, were fitted by two mathematical formulas as follows: (a) $y=a t^{b} e^{-c t}$, where $y$ is the percentage of ${ }^{\star} \mathrm{C}$ excretion in breath per hour; $t$ is the time in hours; and a, b and $c$ are regression estimated constants and (b) $\mathrm{y}=\mathrm{mk} \beta \mathrm{e}^{-\mathrm{kt}}\left(1-\mathrm{e}^{-\mathrm{kt} \beta-1}\right)$, where $\mathrm{y}$ is the percentage of ${ }^{\star} \mathrm{C}$ excretion in breath per hour; $t$ is time in hours; and $\mathrm{m}, \mathrm{k}$, and $\beta$ are regression estimated constants with $\mathrm{m}$ the cumulative ${ }^{\star} \mathrm{C}$ recovery when time is infinite. The results of this nonlinear regression analysis (SAS: PROC NLIN (24) or EXCEL) allows calculation of three distinctive parameters describing the gastric emptying rate of solids, that is: (1) the gastric half emptying time $\left(t_{1 / 2 b}=\left[60(-1 / k) \ln \left(1-2^{(-1 / \beta)}\right.\right.\right.$ $-66] / 1 \cdot 12$ ) in minutes, (2) the lag phase as defined by Siegel $\left(t_{\text {lagb }}=[60(\ln \beta) / k-66] / 0.94\right)$ in minutes and, (3) the gastric emptying coefficient $(\mathrm{GEC}=\ln (\mathrm{a}))$.

In each subject, the gastric half emptying time, lag phase, and gastric emptying coefficient after erythromycin and after propantheline were compared with the values obtained in the control study using paired comparisons $t$ tests (SAS: PROC MEANS (24)).

To determine the minimum frequency of breath sampling needed to achieve accurate information about the gastric emptying rate, mathematical curve fitting was repeated for the following sampling intervals: six, nine, 12, 15 and 30 minutes. The calculated gastric half emptying time, lag phase, and gastric emptying coefficient of these five different sampling frequencies were compared with the corresponding values obtained by sampling at three minute intervals using paired comparisons $t$ tests (24).

\section{Results}

Figure 1 illustrates a typical ${ }^{14} \mathrm{CO}_{2}$ breath excretion pattern in a subject studied in three test situations - (B) without medication, (A) after erythromycin and, (C) after propantheline. The drugs clearly affect the shape of the ${ }^{14} \mathrm{CO}_{2}$ excretion curve representing the percentage of the dose excreted per hour. Erythromycin increases not only the peak but also the slope of the ascending and descending limb of ${ }^{14} \mathrm{CO}_{2}$ excretion curve. With propantheline both the peak and the slope of the ascending and descend- 
TABLE I The mean $(S D)$ values of the different gastric emptying rate parameters in normal conditions and after the administration of erythromycin and propantheline. Also given is the value of the mathematical fitted curve through the mean data

\begin{tabular}{lllll}
\hline & & $G E C$ & $t_{1 / 2 \mathrm{~b}}(\min )$ & $t_{\text {lagb }}($ min $)$ \\
\hline Normal & Mean (SD) & $3 \cdot 31(0 \cdot 36)$ & $71 \cdot 22(26 \cdot 68)$ & $22 \cdot 78(13 \cdot 75)$ \\
& Fit of mean & $3 \cdot 29$ & $61 \cdot 70$ & $27 \cdot 19$ \\
Erythromycin & Mean (SD) & $3-73(0 \cdot 24)$ & $37 \cdot 44(21 \cdot 32)$ & $4 \cdot 44(11 \cdot 86)$ \\
Propantheline & Fit of mean & $3 \cdot 36$ & $34 \cdot 58$ & $2 \cdot 16$ \\
& Mean (SD) & $2 \cdot 69(0 \cdot 56)$ & $141 \cdot 44(87 \cdot 74)$ & $38 \cdot 44(29 \cdot 32)$ \\
& Fit of mean & $2 \cdot 72$ & $98 \cdot 45$ & $37 \cdot 26$ \\
\hline
\end{tabular}

$\mathrm{GEC}=$ gastric emptying coefficient; $\mathrm{t}_{1 / \mathrm{b}}(\min )=$ half emptying time $(\min ) ; t_{\text {lagb }}(\min )=$ lag time $(\min )$.

ing limb of the ${ }^{14} \mathrm{CO}_{2}$ excretion curve are decreased.

Figure 2 shows the mean ${ }^{14} \mathrm{CO}_{2}$ excretion curve, expressed as the percentage dose of ${ }^{14} \mathrm{CO}_{2}$ excreted per hour, together with the mathematical curve fitting. An interesting phenomenon is the early (albeit not statistically significant) increase in ${ }^{14} \mathrm{CO}_{2}$ excretion after the administration of propantheline.

Mathematical analysis of the ${ }^{14} \mathrm{CO}_{2}$ excretion patterns yields additional useful information Table I shows the mean values of the gastric emptying coefficients, gastric half emptying times, and lag phases for the three different gastric emptying studies. Also given are the values of these parameters as calculated from the mathematically fitted equation of the mean values of ${ }^{14} \mathrm{CO}_{2}$ excretion. Figure 3 shows the individual values of gastric emptying coefficient, gastric half emptying time, and the lag phase for each of the three test situations. In eight of the nine subjects, the gastric emptying coefficient was greater after erythromycin than control (Fig 3(A)). After administration of propantheline all nine subjects had a decreased gastric emptying coefficient. The difference between control and pharmacologically modified gastric emptying coefficients is statistically significant (erythromycin: $\mathrm{p}=0.0043$; propantheline: $p=0 \cdot 0007)$. Figure $3(B)$ shows that gastric half emptying times decreased after erythromycin $(p=0.0020)$ and increased after propantheline $(p=0.0168)$ in all subjects. The great difference between the mean value and the value of the mathematically fitted mean after propantheline is due to presence of two extremely delayed gastric emptying patterns. The lag phase, shown in Figure $3(\mathrm{C})$, decreased in eight of the nine subjects after erythromycin $(p=0.0044)$, but increased in only six of them after propantheline $(p=0 \cdot 1214)$. In one subject, a lag phase could not be shown in any of the three tests.

In addition, the values of the gastric emptying coefficient, gastric half emptying time, and the lag phase calculated from the curve fitting formulas based on the breath sample data at three, six, nine, 12, 15 and 30 minutes intervals were weighted in order to investigate the sensitivity of the breath test parameters in relation to sampling frequency. Paired comparisons $t$ test showed no statistically significant difference between the three minute interval sampling and any of the other interval sampling times (see Table II). Some additional considerations have to be made, however, about the discriminative value of the breath test parameters between normal and pharmacologically modified gastric emptying in relation to the sampling frequency. With regard to the gastric half emptying time (Table II), the discriminative value remained intact up to sampling intervals of $\mathbf{3 0}$ minutes: in all subjects, the half emptying time remained longer with propantheline and shorter with erythromycin up to sampling intervals of 30 minutes. The gastric emptying coefficient, however, became slightly less discriminative at 15 minute intervals. At this sampling interval, the gastric emptying coefficient did not increase after erythromycin in one subject, but remained unchanged. At 30 minute interval sampling, the gastric emptying coefficient even decreased in three subjects with erythromycin. As far as the lag phase is concerned, results are discriminative for sampling intervals from three up to 30 minutes, with the exception of two gastric emptying studies after propantheline. In these two cases the lag phase of the basal and propantheline modified gastric emptying study changed by a few minutes only.

\section{Discussion}

We recently developed a breath test - the ${ }^{\star} \mathrm{C}$ octanoic acid breath test - to measure the gastric emptying rate of solids. ${ }^{17}$ Octanoic acid is fully retained in egg yolk during mixing and grinding in the stomach, but is rapidly liberated in the duodenum. Being a medium-chain fatty acid, it
Figure 3: Comparison of the gastric emptying rate parameters for each individual in the three test situations. (A) shows the changes of the gastric emptying coefficient, $(B)$ changes in the gastric half emptying time, and $(C)$ in the lag phase.
A Gastric emptying coefficient

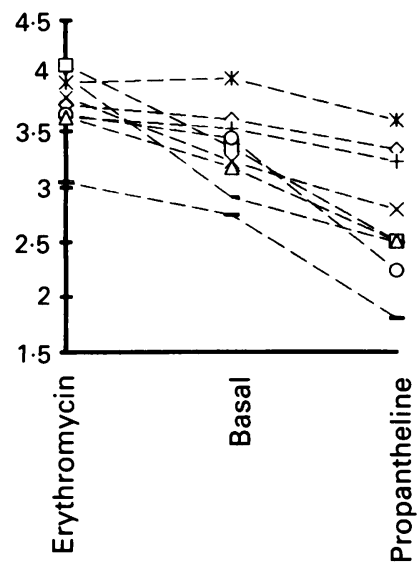

B Half emptying time (min)

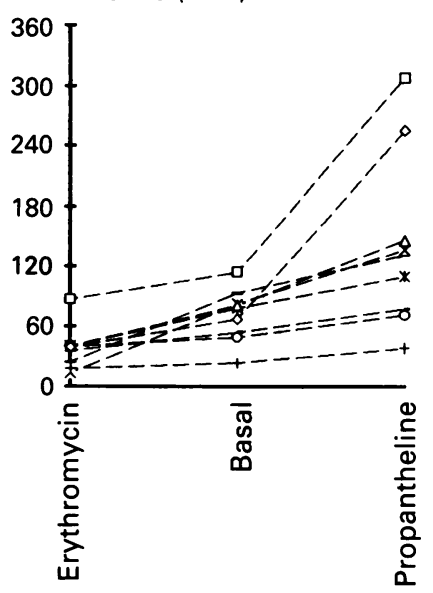

C Lag phase (min)

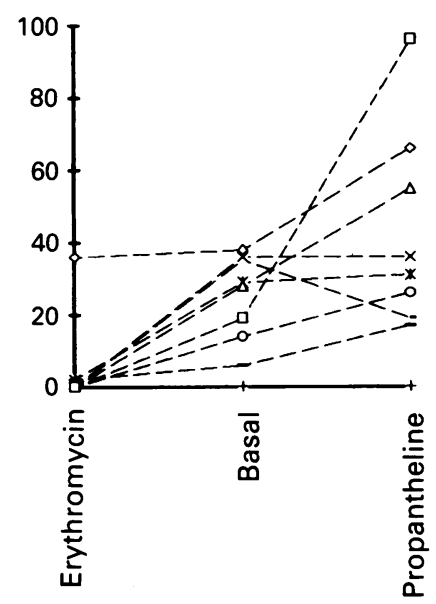


TABLE II Results of the paired comparisons t tests of different sampling intervals for the different gastric emptying parameters. The mean difference between two sample procedures is given for the 27 gastric emptying studies executed together with the SD and the p value for the test

\begin{tabular}{|c|c|c|c|c|c|c|}
\hline \multirow{2}{*}{$\begin{array}{l}\text { Sampling } \\
\text { interval } \\
\text { time (min) }\end{array}$} & \multicolumn{2}{|l|}{$G E C$} & \multicolumn{2}{|l|}{$t_{1 / 2 b}(\min )$} & \multicolumn{2}{|l|}{$t_{\text {lagb }}(\min )$} \\
\hline & $\begin{array}{l}\text { Mean difference } \\
(S D)\end{array}$ & $\stackrel{p}{\text { Value }}$ & $\begin{array}{l}\text { Mean difference } \\
(S D)\end{array}$ & $\stackrel{p}{\text { Value }}$ & $\begin{array}{l}\text { Mean difference } \\
(S D)\end{array}$ & $\stackrel{p}{\text { Value }}$ \\
\hline $\begin{array}{l}3-6 \\
3-9 \\
3-12 \\
3-15 \\
3-30\end{array}$ & $\begin{array}{l}-0.01(0.01) \\
-0.01(0.02) \\
-0.02(0.03) \\
-0.04(0.03) \\
-0.10(0.06)\end{array}$ & $\begin{array}{l}0.36 \\
0.45 \\
0 \cdot 44 \\
0 \cdot 22 \\
0.09\end{array}$ & $\begin{array}{r}-1.89(2.09) \\
0.78(5.08) \\
-3.85(4.41) \\
-2.37(4.53) \\
-4.07(6.35)\end{array}$ & $\begin{array}{l}0.37 \\
0.88 \\
0.39 \\
0.60 \\
0.53\end{array}$ & $\begin{array}{r}-3.22(3.34) \\
0.33(1.87) \\
-0.89(1.56) \\
0.52(2.90) \\
-0.44(2.34)\end{array}$ & $\begin{array}{l}0.34 \\
0.86 \\
0 \cdot 11 \\
0 \cdot 86 \\
0 \cdot 85\end{array}$ \\
\hline
\end{tabular}

$\mathrm{GEC}=$ gastric emptying coefficient; $\mathrm{t}_{1 / \mathrm{b}}(\mathrm{min})=$ half emptying time $(\min ) ; \mathrm{t}_{\text {lagb }}(\min )=$ lag time $(\min )$.

is quickly absorbed and transported to the liver via the vena portae where it is rapidly oxidised (no carnitine required to enter the mitochondria) ${ }^{18}$ and extensively metabolised to $\mathrm{CO}_{2}$, ${ }^{19}$ instead of being used in hepatic lipid synthesis. ${ }^{20}$ The rate of ${ }^{\star} \mathrm{CO}_{2}$ excretion in breath mainly depends on gastric emptying of the ${ }^{\star} \mathrm{C}$ octanoic acid labelled test meal.

The ${ }^{\star} \mathrm{C}$ labelled octanoic acid breath test has several advantages over other methods that measure the gastric emptying rate in humans. It is non-invasive and easy to perform for the patients. ${ }^{14} \mathrm{C}$ octanoic acid means that the amount of radiation used is reduced considerably, and no radiation is involved with ${ }^{13} \mathrm{C}$ octanoic acid as marker of the solid test meal. Moreover, the ${ }^{13} \mathrm{C}$ labelled octanoic breath test makes it possible to do repeated gastric emptying studies, even in children and pregnant women.

In this study, we modulated gastric emptying pharmacologically in order to investigate the sensitivity of the test in normal subjects. Erythromycin, a potent stimulator of gastrointestinal activity, caused a shift in the ${ }^{\star} \mathrm{CO}_{2}$ excretion curve to the left on the time axis, which can only be explained by an acceleration of gastric emptying. The acceleration included a shortening of both the lag phase and the gastric half emptying time in all subjects studied. The gastric emptying coefficient, an overall parameter for the gastric emptying rate was increased in all but one volunteer by erythromycin. In this subject, the basal gastric emptying rate was already very fast. As erythromycin, at the recommended dose of $200 \mathrm{mg}^{14}$ enhances gastric emptying to normal values in patients with gastroparesis diabeticorum, larger doses were $\stackrel{\vec{\rho}}{\Omega}$ not used to reduce side effects. This study 0 showed that a dose of $200 \mathrm{mg}$ of erythromycin $\frac{\overline{ }}{\bar{D}}$ accelerates gastric emptying in healthy volun- $\frac{\bar{\sigma}}{\bar{D}}$ teers, even in subjects with a very fast basal $\stackrel{\curvearrowright}{\varrho}$ gastric emptying rate. Propantheline, a syntheic के quaternary ammonium anticholinergic drug, $\overrightarrow{0}$ delays gastric emptying of fluids in an oral dose of $30 \mathrm{mg}$, without causing major anticholinergic $\vec{\omega}$ side effects. ${ }^{22}$ Our study showed that a single dose of $30 \mathrm{mg}$ propantheline also delays gastric emptying of solids, with a fall in the gastric w emptying coefficient and an increase of the $\omega$ gastric half emptying time in all subjects examined. However, the lag phase is not significantly altered. This is due to the early increase of the ${ }^{\star} \mathrm{CO}_{2}$ excretion in most subjects after $\vec{z}$ administration of propantheline (see Fig 2), ฏ probably caused by an initial relaxation of the $\stackrel{\circ}{工}$ pylorus, which at this dose is not sufficient to $\vec{\varphi}$ alter significantly the overall gastric emptying of solids. It would be interesting to study the effects of larger doses of propantheline.

Mathematical analysis of the breath sample data with simulation of different sampling intervals indicates that sampling at short intervals is needed in subjects with a rapid gastric emptying pattern, whereas sampling has to extend over a long period of time with very slow gastric emptying patterns. In this study, lengthening the sampling interval showed that the breath test parameters remained accurate and discriminative for up to 15 minutes. Therefore, sampling every 15 minutes over a four hour period seems to be the best schedule to ensure reliable results.

TABLE III Values of the gastric emptying coefficient $(G E C)$, half emptying time $\left(t_{1 / \mathrm{b}}\right)$, and lag phase ( $\left.t_{\text {lagb }}\right)$ :derived from mathematical curve fitting when taking into account three, six, nine, 12, 15, and 30 minute interval sampling during the first 90 minutes of the breath test

\begin{tabular}{|c|c|c|c|c|c|c|c|c|c|c|c|c|c|c|c|c|c|c|}
\hline \multirow[b]{2}{*}{ Study/subject no } & \multicolumn{6}{|c|}{ GEC (sampling interval (min)) } & \multicolumn{6}{|c|}{$t_{1 / 2 \mathrm{~b}}(\min )($ sampling interval $(\min ))$} & \multicolumn{6}{|c|}{$\underline{t_{\text {lagb }}(\min )(\text { sampling interval }(\min ))}$} \\
\hline & 3 & 6 & 9 & 12 & 15 & 30 & 3 & 6 & 9 & 12 & 15 & 30 & 3 & 6 & 9 & 12 & 15 & 30 \\
\hline $\begin{array}{c}\text { Normal: } \\
1 \\
2 \\
3 \\
4 \\
5 \\
6 \\
7 \\
8 \\
9\end{array}$ & $\begin{array}{l}2.89 \\
3.27 \\
3.38 \\
3.18 \\
3.93 \\
3.38 \\
2.74 \\
3.60 \\
3.43\end{array}$ & $\begin{array}{l}2.88 \\
3.24 \\
3.35 \\
3.22 \\
3.81 \\
3.37 \\
2.78 \\
3.60 \\
3.42\end{array}$ & $\begin{array}{l}2.84 \\
3.23 \\
3.39 \\
3.21 \\
3.73 \\
3.37 \\
2.80 \\
3.60 \\
3.42\end{array}$ & $\begin{array}{l}2.83 \\
3.19 \\
3.32 \\
3.25 \\
3.78 \\
3.41 \\
2.81 \\
3.58 \\
3.42\end{array}$ & $\begin{array}{l}2.81 \\
3.21 \\
3.38 \\
3.26 \\
3.74 \\
3.43 \\
2.79 \\
3.54 \\
3.39\end{array}$ & $\begin{array}{l}2.74 \\
3.13 \\
3.37 \\
3.32 \\
3.37 \\
3.40 \\
2.86 \\
3.50 \\
3.40\end{array}$ & $\begin{array}{r}93 \\
78 \\
82 \\
81 \\
23 \\
54 \\
114 \\
49 \\
67\end{array}$ & $\begin{array}{r}94 \\
79 \\
83 \\
79 \\
26 \\
54 \\
108 \\
46 \\
67\end{array}$ & $\begin{array}{r}95 \\
79 \\
80 \\
78 \\
27 \\
53 \\
106 \\
48 \\
67\end{array}$ & $\begin{array}{r}95 \\
81 \\
82 \\
77 \\
27 \\
53 \\
106 \\
46 \\
67\end{array}$ & $\begin{array}{r}97 \\
79 \\
80 \\
76 \\
27 \\
51 \\
108 \\
47 \\
68\end{array}$ & $\begin{array}{r}104 \\
85 \\
81 \\
73 \\
29 \\
52 \\
100 \\
48 \\
68\end{array}$ & $\begin{array}{r}35 \\
29 \\
36 \\
28 \\
0 \\
14 \\
38 \\
6 \\
19\end{array}$ & $\begin{array}{r}35 \\
29 \\
36 \\
28 \\
0 \\
14 \\
36 \\
5 \\
19\end{array}$ & $\begin{array}{r}36 \\
29 \\
35 \\
27 \\
0 \\
13 \\
37 \\
6 \\
19\end{array}$ & $\begin{array}{r}35 \\
30 \\
35 \\
28 \\
0 \\
14 \\
37 \\
5 \\
19\end{array}$ & $\begin{array}{r}36 \\
30 \\
35 \\
27 \\
0 \\
13 \\
36 \\
5 \\
19\end{array}$ & $\begin{array}{r}36 \\
31 \\
36 \\
28 \\
0 \\
13 \\
36 \\
4 \\
20\end{array}$ \\
\hline $\begin{array}{c}\text { Erythromycin: } \\
1 \\
2 \\
3 \\
4 \\
5 \\
6 \\
7 \\
8 \\
9\end{array}$ & $\begin{array}{l}3.89 \\
3.82 \\
4.09 \\
3.64 \\
3.85 \\
3.62 \\
3.20 \\
3.73 \\
3.74\end{array}$ & $\begin{array}{l}3.83 \\
3.80 \\
3.93 \\
3.61 \\
3.77 \\
3.58 \\
3.26 \\
3.73 \\
3.71\end{array}$ & $\begin{array}{l}3 \cdot 77 \\
3 \cdot 80 \\
3 \cdot 81 \\
3.62 \\
3 \cdot 76 \\
3.50 \\
3 \cdot 29 \\
3.67 \\
3 \cdot 76\end{array}$ & $\begin{array}{l}3.71 \\
3.76 \\
3.72 \\
3.60 \\
3.63 \\
3.48 \\
3.37 \\
3.73 \\
3.69\end{array}$ & $\begin{array}{l}3.61 \\
3.69 \\
3.56 \\
3.59 \\
3.63 \\
3.43 \\
3.35 \\
3.60 \\
3.72\end{array}$ & $\begin{array}{l}3.28 \\
3.51 \\
3.27 \\
3.55 \\
3.34 \\
3.24 \\
3.43 \\
3.52 \\
3.64\end{array}$ & $\begin{array}{l}24 \\
40 \\
13 \\
40 \\
18 \\
36 \\
87 \\
40 \\
39\end{array}$ & $\begin{array}{l}30 \\
40 \\
18 \\
40 \\
19 \\
38 \\
82 \\
39 \\
39\end{array}$ & $\begin{array}{l}32 \\
40 \\
22 \\
41 \\
20 \\
41 \\
81 \\
38 \\
39\end{array}$ & $\begin{array}{l}35 \\
41 \\
24 \\
40 \\
21 \\
41 \\
77 \\
38 \\
39\end{array}$ & $\begin{array}{l}36 \\
42 \\
26 \\
42 \\
22 \\
40 \\
77 \\
38 \\
38\end{array}$ & $\begin{array}{l}40 \\
42 \\
28 \\
43 \\
24 \\
42 \\
74 \\
39 \\
40\end{array}$ & $\begin{array}{r}0 \\
2 \\
0 \\
0 \\
0 \\
0 \\
36 \\
2 \\
0\end{array}$ & $\begin{array}{r}0 \\
1 \\
0 \\
0 \\
0 \\
0 \\
34 \\
1 \\
0\end{array}$ & $\begin{array}{r}0 \\
2 \\
0 \\
0 \\
0 \\
0 \\
33 \\
0 \\
0\end{array}$ & $\begin{array}{r}0 \\
2 \\
0 \\
0 \\
0 \\
0 \\
33 \\
1 \\
0\end{array}$ & $\begin{array}{r}0 \\
1 \\
0 \\
0 \\
0 \\
0 \\
33 \\
0 \\
0\end{array}$ & $\begin{array}{r}0 \\
0 \\
0 \\
0 \\
0 \\
0 \\
33 \\
0 \\
0\end{array}$ \\
\hline $\begin{array}{l}\text { Propanthline: } \\
1 \\
2 \\
3 \\
4 \\
5 \\
6 \\
7 \\
8 \\
9\end{array}$ & $\begin{array}{l}2.51 \\
2.79 \\
2.52 \\
2.51 \\
3.54 \\
3.22 \\
1.72 \\
3.21 \\
2.23\end{array}$ & $\begin{array}{l}2.44 \\
2.82 \\
2.51 \\
2.52 \\
3.53 \\
3.28 \\
1.78 \\
3.23 \\
2.35\end{array}$ & $\begin{array}{l}2.43 \\
2.84 \\
2.53 \\
2.52 \\
3.51 \\
3.36 \\
1.81 \\
3.21 \\
2.45\end{array}$ & $\begin{array}{l}2.37 \\
2.87 \\
2.49 \\
2.51 \\
3.51 \\
3.37 \\
1.85 \\
3.27 \\
2.55\end{array}$ & $\begin{array}{l}2.32 \\
2.88 \\
2.51 \\
2.53 \\
3.49 \\
3.38 \\
1.91 \\
3.24 \\
2.54\end{array}$ & $\begin{array}{l}2.27 \\
2.96 \\
2.50 \\
2.55 \\
3.37 \\
3.46 \\
2.00 \\
3.29 \\
2.65\end{array}$ & $\begin{array}{r}131 \\
110 \\
137 \\
146 \\
38 \\
77 \\
308 \\
71 \\
255\end{array}$ & $\begin{array}{r}148 \\
106 \\
136 \\
147 \\
39 \\
73 \\
299 \\
68 \\
204\end{array}$ & $\begin{array}{r}147 \\
104 \\
134 \\
142 \\
39 \\
70 \\
410 \\
68 \\
171\end{array}$ & $\begin{array}{r}164 \\
102 \\
139 \\
146 \\
39 \\
69 \\
287 \\
65 \\
146\end{array}$ & $\begin{array}{r}183 \\
99 \\
136 \\
143 \\
40 \\
68 \\
307 \\
67 \\
150\end{array}$ & $\begin{array}{r}219 \\
93 \\
134 \\
139 \\
40 \\
65 \\
240 \\
65 \\
134\end{array}$ & $\begin{array}{r}19 \\
31 \\
36 \\
55 \\
0 \\
26 \\
66 \\
17 \\
96\end{array}$ & $\begin{array}{r}22 \\
29 \\
35 \\
55 \\
0 \\
25 \\
76 \\
16 \\
78\end{array}$ & $\begin{array}{r}21 \\
31 \\
36 \\
54 \\
0 \\
24 \\
109 \\
16 \\
72\end{array}$ & $\begin{array}{r}20 \\
29 \\
33 \\
55 \\
0 \\
24 \\
60 \\
15 \\
65\end{array}$ & $\begin{array}{r}16 \\
28 \\
34 \\
54 \\
0 \\
23 \\
135 \\
17 \\
63\end{array}$ & $\begin{array}{r}8 \\
29 \\
37 \\
54 \\
0 \\
23 \\
114 \\
18 \\
59\end{array}$ \\
\hline
\end{tabular}


We conclude that the ${ }^{\star} \mathrm{C}$ labelled octanoic breath test is useful for measuring the gastric emptying rate of solids and is sensitive enough to detect pharmacological effects on gastric motor activity.

l Minami H, McCallum RW. The physiology and pathophysiology of gastric emptying in humans. Gastroenterology physiology of gastric

2 Amidon GL, DeBrincat GA, Najib N. Effects of gravity on gastric emptying, intestinal transit, and drug absorption. f Clin Pharmacol 1991; 31: 968-73.

3 Roland J, Dobbeleir A, Vandevivere J, Ham HR. Effect of mild mental stress on solid phase gastric emptyiong in healthy subjects. Nucl Med Comm 1990; 11: 319-26.

4 Nowak A, Jonderko K, Kaczor R, Nowak S, Skrzypek D. Cigarette smoking delays gastric emptying of radiolabeled solid foods in healthy smokers. Scand $\mathcal{F}$ Gastroenterol 1987 22: 54-8.

5 Read NW, Al Janabi MN, Bates TE, Barber DC. Effect of gastrointestinal intubation on the passage of a solid meal
through the stomach and small intestine in humans. Gastrothrough the stomach and small

6 Ramsbottom N, Hunt JN. Effect of exercise on gastric emptying and gastric secretion. Digestion 1974; 10: 1-8.

Thompson DG, Richelson E, Malagelada JR. Pertubation of the upper gastrointestinal function by cold stress. Gut 1983; 24: $277-83$.

8 Chaudhuri TK, Fink S. Update: pharmaceuticals and gastric emptying. Am 7 Gastroenterol 1990; 85: 223-30.

9 Nimmo WS, Heading RC, Wilson J, Tothill P, Prescott LF. Inhibition of gastric emptying and drug absorption by narcotic analgesics. Br f Clin Pharmac 1975; 2: 509-13.

10 Hurwitz A, Robinson RG, Vats TS, Whittier FC, Herrin WF. Effects of antacids on gastric emptying. Gastroenterology 1976; 71: 268-73.

11 Jian R, Ducrot F, Piedeloup C, Mary JY, Najean Y, Bernier JJ. Measurement of gastric emptying in dyspeptic patients: effect of a new gastrokinetic agent (cisapride). Gut 1985; 26: 352-8.
12 Nimmo J, Heading RC, Tothill P, Prescott LF. Pharmacological modification of gastric emptying: effects of propantheline and metoclopramide on paracetamol absorption. BMF 1973; 1: 587-9.

13 Janssens J, Peeters TL, Vantrappen G, Tack J, Urbain JL, De Roo M, Muls E, Bouillon R. Improvement of gastric emptying in diabetic gastroparesis by erythromycin. New Engl f Med 1990; 322: 1028-31.

14 Zara GP, Thompson HH, Pilot MA, Ritchie HD. Effects of erythromycin on gastrointestinal tract motility. $\mathcal{F}$ Antimicrob erythromycin on gastroin $1985 ; 16:$ A $175-9$.

15 Tomomasa T, Kuroume T, Arai H, Wakabayashi K, Itoh Z. Erythromycin induces migrating motor complex in human gastrointestinal tract. Dig Dis Sci 1986; 31: 157-61.

16 Peeters TL, Matthijs G Depoortere I, Cachet T, Hoogmartens J, Vantrappen G. Erythromycin is a motilin receptor agonist. Am F P hysiol 1989; 257: G470-4.

17 Ghoos YF, Maes BD, Geypens BJ, Hiele MI, Rutgeerts PJ, Vantrappen G. Measurement of gastric emptying rate of solids by means of a carbon labelled octanoic acid breath test. Gastroenterology 1993; 104: 1640-7.

18 Bach AC, Babayan VK. Medium-chain triglycerides: an update. Am F Clin Nutr 1982; 36: 950-62.

19 McGary JD Foster DW. Regulation of hepatic fatty acid oxidation and ketone body production. Ann Rev Biochem oxidation and keto

20 Scheig R. Hepatic metabolism of medium chain fatty acids. In: Senior JR, ed. Medium chain triglycerides. Philadelphia, PA: University of Pennysylvania Press, 1968: 39-49.

21 Haycock G, Schwartz G, Wisotsky D. Geometric method for measuring body surface area: a height-weight formula validated in infants, children and adults. $\mathcal{F}$ Pediatr 1978; 93: 62-6.

22 Hurwitz A, Robinson RG, Herrin WF. Prolongation of gastric emptying by oral propantheline. Clin Pharmacol Ther 1977; 22: 206-10.

23 Brömster D, Calberger G, Lundh G, Möller J, Rosen A. The effect of some oral anticholinergics on gastric emptying, $\mathrm{pH}$ and osmolarity in man. Scand $\mathrm{f}$ Gastroenterol 1970; 4: and osm 185 .

24 SAS Institute inc. SAS/STAT user's guide. Release 6.03 Edition 1 SAS Institute Inc, Raleigh, NC 1988; 675-712. 


\section{BOOK REVIEWS}

Gastrointestinal Endoscopy - Basic Principles and Practice. By J Baillie. (Pp 149; illustrated; $£ 20.00$.) Oxford: Butterworth Heinemann, 1992

This slim book is written primarily for trainees in endoscopy to 'fill some of the gaps found in all training programmes'. In this, it undoubtedly succeeds though whether it will appeal to the wider audience hoped for by the author is in doubt. John Baillie's friendly, avuncular, and informative style is a pleasure to read for the most part, although wordy at times. The general layout is very similar to that of the major competitor in the field, Cotton and Williams. There are sections on endoscopes, endoscopy, sedation, the ASGE training guidelines, and teaching aids as well as chapters on gastroscopy and basic procedures, colonoscopy and, the best of all the procedure related sections, endoscopic retrograde choliopangiopancreatography. There are helpful hints in many areas, written with humour and obviously much experience of the problems encountered by trainees. Some of them would be of help also to the more experienced.

Trainees at varying stages of maturity to whom I have shown the book commented that the initial section seems suitable for those who have never seen an endoscope or an endoscopy unit but, thereafter, rapidly becomes redundant. This is perhaps inevitable in a book that intends to be comprehensive for beginners. Similar comments were made about parts of the upper gastrointestinal section. The colonoscopy section describes techniques, such as entering the ileocaecal valve that I cannot make work in practice. The book is illustrated by rather obscure diagrams, which hinder rather than help. Sadly the whole enterprise is weakened by poor photographs, some of which were so dark in my copy as to be almost useless. The quality of the diagrams is also disappointing. Illustrations are an important part of any guide such as this and their poor quality is a serious problem. The major rival in this market - Cotton and Williams - has had the benefit of revision through previous editions and was preferred by all the trainees who had seen both. I am sure that John Baillie's book would improve in subsequent iterations, and I hope that it will sell enough in the face of the competition to justify a second go.

P D FAIRCLOUGH

Handbook of Immunopharmacology of the Gastrointestinal System. Edited by J L Wallace. (Pp 193; illustrated; $£ 40.00$.) London: Academic Press, 1993.

This is a timely contribution to a rapidly developing field - indeed, the field in many areas has already left some of the chapters looking rather elderly. The book begins with detailed reviews of the neuromodulation of gastrointestinal immune and inflammatory responses and the immune modulation of epithelial function and of motor activity. The function of neutrophils and mast cells in an inflammatory response is well covered. Lymphocyte and macrophage functions and their control are not discussed as such but they are covered to a degree by an excellent review on cytokines - it is inevitable that at least three more interleukins have been described since it was written. The reviews of eicosanoids, nitric oxide, and platelet activation factor are good. Perhaps the only slight disappointment was the final chapter on the effects of glucocorticoids on gastrointestinal inflammation as it fails to go beyond rather standard information on the effect of these drugs on the release of mediators and cytokine and on an inflammatory response in general. The fascinating events at molecular level that lead to these effects are not discussed at all.

This book is not for the casual reader. It is a gold mine of information and the detailed referencing will be invaluable to the clinical investigator. Some of the chapters are hard going, largely because of a failure to write elegant English. My other criticism is that virtually every cell, protein, mediator or substance is abbreviated ab initio. A list of abbreviations (termed 'a glossary') is given at the back but I looked through the book twice before finding it - at least there was suspense before finding what a FLAP was! Nevertheless, the book is well produced, well illustrated with line diagrams and experimental data, and provides excellent in depth reviews. My review copy is likely to disappear rapidly into the briefcases of eager research fellows.

D P JEWELL

*5-lipoxygenase activating protein.

Surgery of the Anus, Rectum and Colon. By M R B Keighley and N S Williams. (Pp 2448 and index; illustrated; $£ 280.00$.) London: W B Saunders, 1993.

These volumes represent a magnificent achievement and follow in the tradition set by its classic predecessor written by Professor John Goligher. It should not be regarded as the next edition of a previous text, even if it uses the same title, but an excellent new creation by Michael Keighley and Norman Williams.

Coloproctology is now emerging as a specialty, a multidisciplinary specialty, and so the question has to be asked whether one or two authors can hope to cover all the subject matter. While the authors have covered much of the ground themselves they have assembled a small team of appropriate experts to assist them and so recognise the difficulty. On this occasion the experts cover other relevant disciplines such as genitourinary medicine, urology, gynaecology, tropical disorders, and paediatrics. In subsequent editions physicians, radiologists, clinical geneticists, and histopathologists will probably be required as the text will inevitably need to cover the surgically driven specialty as a whole rather than be devoted to surgical aspects only. Such recruitment will strengthen the weaker areas.
These general comments must not detract from the immense worth of these two volumes (they weigh $16 \mathrm{lb}$ !). Not only are they well researched and referenced but they are also pleasingly written with good illustrations and detailed index. Of particular value are the chapters on functional problems and the surgical techniques for inflammatory bowel disease. The postscript on laparoscopic techniques is also excellent with its cautionary critique.

There is no doubt that these volumes will be used by many in this country and overseas and greatly assist in the promotion of coloproctology as a specialty. The authors deserve congratulations and it is to be hoped that they will be rewarded in its sales. They have laid an excellent foundation for the future.

J P S THOMSON

If you wish to order or require further information regarding the titles reviewed here, please write to or telephone the BMJ Bookshop, PO Box 295, London WC1H 9JR Tel: 071383 6244. Fax: 0713836662 Books are supplied post free in the UK and for BFPO addresses. Overseas customers should add $15 \%$ for postage and packing. Payment can be made by cheque in sterling drawn on a UK bank or by credit card (Mastercard, Visa, or American Express) stating card number, expiry date, and full name. (The price and availability are occasionally subject to revision by the Publishers.)

\section{NOTES}

\section{European venture}

The North of England Gastroenterology Society has created a European Venture Fund through donations from industry to support younger members presenting original workat European meetings. Three travelling Fellowships were awarded in 1993 to Dr Mark Cotterill of Leigh Infirmary, Mr Thomas Wright of the Royal Liverpool Hospital, and Miss Tasmin Greenwell of the Northern General Hospital. Their work was well received and stimulated much discussion. The Society plans to continue to support its younger members in this way.

\section{Corrections}

An error occurred in this paper by $\mathrm{Dr}$ Bart Maes et al (Gut 1994; 35: 333-7). The symbols in Figure 2 should have been $0=$ after erythromycin, $+=$ normal, $\triangle=$ after propantheline.

An editorial error occurred in this paper by Dr Biørn Østenstad et al (Gut 1994; 35: 382-70). The fourteenth line in the abstract should have read peripheral blood lymphocytes (not lamina propria lymphocytes). 